\title{
Development Of Executive Information Systems Of Cirebon City Government (Case Study: Department Of Communication, Informatics And Statistics)
}

Pengembangan Sistem Informasi Eksekutif Pemerintahan Kota Cirebon (Studi Kasus : Dinas Komunikasi, Informatika, Dan Statistik)

Muhammad Nur Hendra Alvianto', Herry Sofyan², Juwairiah³

1,2,3 Sistem Informasi, Universitas Pembangunan Nasional Veteran Yogyakarta, Indonesia

1*nurhendra.alvi1103@gmail.com, ${ }^{2}$ herrysofyan@gmail.com, ${ }^{3}$ juwai_riah@yahoo.com

*: Penulis korenspondensi (corresponding author)

\section{Informasi Artikel}

Received: March 2021

Revised: April 2021

Accepted: May 2021

Published: August 2021

Keywords: Executive Information Systems, Dill Down, GRAPPLE

Kata kunci: Sistem Informasi Eksekutif, Dill Down, GRAPPLE
Abstract

Purpose: Developing an executive information system to meet the information needs of the Mayor, Deputy Mayor, Regional Secretary and the heads of SKPD within the Cirebon City Government.

Method: Using the drill down method for solving information on executive information systems and the GRAPPLE system development method

Result: The development of an executive information system in Cirebon city government has assisted the executive, consisting of mayors, deputy mayors and regional secretaries and middle executives consisting of skpd within the Cirebon city government. Cirebon city government executive information system consists of five sectors in the city of Cirebon, namely economy, health, population, education and government. The results of the validation testing are $100 \%$ and the average user acceptance testing results are $85.29 \%$.

State of the art: Based on previous research, this study has the same characteristics but in the development of executive information systems it has differences in objects and methods of software development.

Abstrak

Tujuan: Mengembangkan sistem informasi eksekutif untuk memenuhi kebutuhan informasi untuk Wali Kota, Wakil Wali Kota, Sekretaris Daerah dan jajaran kepala SKPD di lingkungan Pemerintah Kota Cirebon.

Metode: Menggunakan metode drill down untuk pemecahan informasi pada sistem informasi eksekutif dan metode pengembangan sistem GRAPPLE

Hasil: Pengembangan sistem informasi eksekutif di pemerintahan kota Cirebon telah membantu eksekutif yaitu 
terdiri dari wali kota, wakil walikota dan sekretaris daerah dan middle executive yang terdiri dari kepada skpd di lingkungan pemerintahan kota Cirebon. Sistem informasi eksekutif pemerintahan kota Cirebon teridiri dari lima sektor yang ada di kota Cirebon yaitu ekonomi, kesehatan, kependudukan, pendidikan dan pemerintahan. Hasil pengujian validation testing mendapat $100 \%$ dan hasil ratarata user acceptance testing $85.29 \%$.

State of the art: Berdasarkan penelitian yang telah dilakukan sebelumnya, pada penelitian ini memiliki karakteristik yang sama namun pada pengembangan sistem informasi eksekutif memiliki perbedaan pada object dan metode pengembangan perangkat lunak

\section{Pendahuluan}

Kebutuhan informasi bagi keberlangsungan dari kinerja organisasi merupakan hal yang sangat penting [1]-[3]. Informasi yang dibutuhkan eksekutif diambil dari data yang diolah secara detail untuk menghasilkan informasi yang dapat digunakan untuk mengidentifikasi masalah dan melakukan pengambilan keputusan. Sistem Informasi Eksekutif digunakan untuk mendukung kebutuhan informasi bagi eksekutif dalam meringkas, menyaring dan memperoleh informasi secara detail yang digunakan untuk mengindentifikasi masalah dan melakukan pengambilan keputusan [4]-[7].Salah satu organisasi yang membutuhkan penerapan sistem informasi eksekutif yaitu Pemerintah Kota Cirebon.

Pemerintah Kota Cirebon saat ini sedang mengembangkan sistem informasi eksekutif untuk memenuhi kebutuhan informasi bagi para eksekutif. Dinas Komunikasi, Informatika dan Statistik sebagai penanggung jawab dalam menyediakan dan mengembangkan teknologi informasi di lingkungan Pemerintahan Kota Cirebon. Selama ini ketika eksekutif membutuhkan informasi yaitu Wali Kota Cirebon untuk melakukan pengambilan kebijakan membutuhkan waktu yang panjang dengan terlebih dahulu menghubungi dinas terkait sebelum diserahkan kembali ke wali kota untuk dilakukan pengambilan kebijakan. Menurut Kepala Bidang Statistik Sektoral dan Persandian di lingkungan pemerintahan Kota Cirebon berdasarkan permasalahan tersebut dalam ketersediaan informasi bagi wali kota dengan adanya proses yang panjang akan berdampak pada pengambilan kebijakan dan pelayanan kepada masyarakat Kota Cirebon.

Terdapat beberapa penelitian yang telah dilakukan pada pengembangan Sistem Informasi Eksekutif pada Pemerintahan Menurut penelitian [8] yaitu dengan melakukan analisis dan perancangan sistem informasi eksekutif pada Pemerintah Kabupaten Sidoarjo. Metode yang digunakan pada penelitian ini yaitu Object-Oriented Analysis and Design dan Traceability Matrix, kedua metode tersebut digunakan untuk melakukan analisis perancangan sistem informasi dan pengujian sistem informasi. Hasil dari penelitian ini yaitu berupa pemodelan proses bisnis dan analisis perancangan sistem dengan menggunakan UML Design. Penggunaan metode Traceability Matrix digunakan untuk melakukan pengujian analisis perangcangan sistem informasi. Terdapat beberapa kekurangan pada penelitian yang dilakukan yaitu belum dilakukan implementasi sistem informasi dan pengujian usability di lingkungan Pemerintah Kabupaten Sidoarjo. Kemudian menurut penelitian yang dilakukan oleh [9]yaitu dengan 
membahas rancang bangun sistem informasi eksekutif pada STAHN Gde Pudja Mataram. Pada penelitian ini menggunakan metode pengembangan sistem Waterfall. Hasil yang didapatkan pada penelitian ini berupa hasil perancangan arsitektur pada data warehouse, perancangan sistem dengan menggunakan UML design, implementasi sistem dengan berbasis web serta pengujian sistem dengan menggunakan metode blackbox. Pada penelitian ini memiliki kekurangan yaitu tidak adanya tahapan requirement gathering dan penjabaran mengenai hasil analisis dari requirement gathering dan analisis kebutuhan. Pada penelitian [3] yaitu membahas mengenai sistem informasi eksekutif pada Dinas Pendidikan Kabupaten Purwakarta dengan menggunakan metode pengembangan sistem waterfall. Hasil yang didapatkan pada penelitian ini yaitu berupa hasil dari analisis requirement gathering, desainn sistem dengan menggunakan UML design dan implementasi dari aplikasi. Namun, pada penelitian ini masih memiliki kekurangan yaitu tidak ada hubungannya antara user story dengan analisis kebutuhan dan tidak adanya tahapan pengujian dari sistem informasi eksekutif ini. Selain itu pada tahapan desain terdapat kurang lengkapnya design pada UML Design.

Pada penelitian ini dilakukan pengembangan sistem informasi eksekutif untuk memenuhi kebutuhan informasi di eksekutif pada Pemerintah Kota Cirebon Sistem informasi eksekutif dikembangkan dengan menggunakan metode pengembangan GRAPPLE dan menggunakan metode drill down yang digunakan untuk melakukan pemecahan informasi secara detail dari yang bersifat global dipecah menjadi level yang bersifat khusus. Diharapkan dengan adanya sistem informasi eksekutif pada Pemerintah Kota Cirebon dapat membantu eksekutif dalam menentukan identifikasi masalah yang ada atau pengambilan keputusan.

\section{Metode/Perancangan}

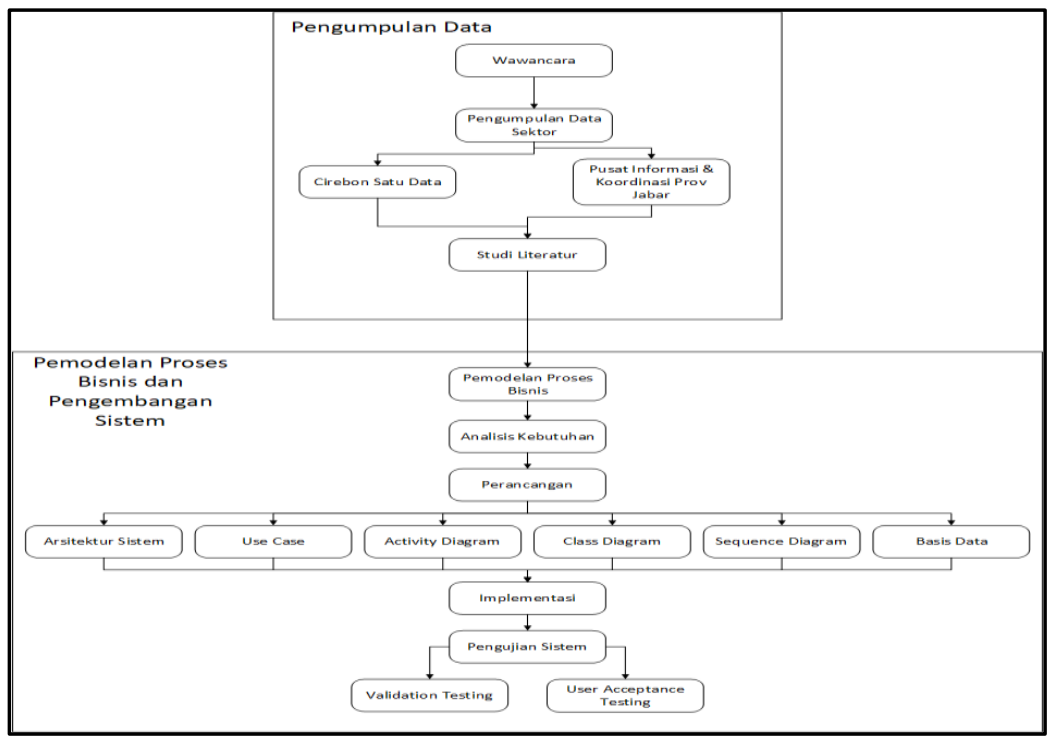

Gambar 1. Metodologi Penelitian 


\subsection{Metode Pengumpulan Data}

\section{a. Wawancara}

Pada tahapan ini melakukan wawancara untuk mendapatkan kebutuhan dari sistem informasi eksekutif. Proses wawancara dilakukan di Dinas Komunikasi, Informatika dan Statistik Kota Cirebon, tepatnya dengan Kepala Bidang Statistik Sektoral dan Persandian Kota Cirebon.

\section{b. Pengambilan data}

Pada tahapan ini melakukan pengambilan data untuk kebutuhan pada informasi di sistem informasi eksekutif. Dataset diambil dari sumber Cirebon Satu Data, Cirebon Satu Data merupakan kumpulan dataset terbuka yang disediakan oleh Pemerintah Kota Cirebon. Data yang digunakan untuk mendukung kebutuhan informasi pada sistem informasi eksekutif terdiri dari beberapa sektor yang ada yaitu ekonomi, pendidikan, pemerintahan, kesehatan dan kependudukan.

\section{c. Studi Literatur}

Studi literatur merupakan sebuah tahapan untuk mempelajari literatur-literatur yang memiliki kaitannya dengan pengembangan sistem informasi eksekutif dan pengolahan informasi dengan menggunakan metode drill down

\section{d. Pemodelan Proses Bisnis}

Proses bisnis merupakan suatu kumpulan dari aktivitas ataupun pekerjaan yang dilakukan secara terstruktur dan saling berkaitan satu dengan yang lain untuk membantu dalam penyelesaian suatu masalah tertentu atau untuk menghasilkan suatu produk atau layanan [10]. Pemodelan proses bisnis terbagi menjadi dua yaitu pemodelan proses bisnis sebelum adanya sistem informasi eksekutif dan pemodelan proses bisnis setelah adanya sistem informasi eksekutif. Pemodelan proses bisnis untuk menggambarkan kedua hal tersebut dengan menggunakan pemodelan proses bisnis as-is dan pemodelan proses bisnis to-be.

\section{e. Pemodelan Proses Bisnis As-Is}

Berdasarkan dari hasil wawancara yang telah dilakukan, diperoleh hasil bagaimana proses bisnis yang dilakukan dalam menyediakan atau menyajikan data untuk wali kota. Proses bisnis yang didapatkan yaitu wali kota meminta terlebih dahulu kepada sekretaris daerah (sekda) untuk menyediakan laporan. Kemudian sekda meminta kepada kepala SKPD/Dinas terkait untuk menyediakan data atau laporan. SKPD/Dinas membuat laporan yang diminta beserta dengan pengolahan datanya. Kemudian laporan yang telah dibuat diserahkan ke sekda dan selanjutnya akan diperiksa oleh wali kota. Kemudian wali kota akan memeriksa dan memastikan apakah membutuhkan tindaklanjut atau tidaknya. Pada Gambar 2. menggambarkan proses bisnis yang dilakukan sebelum adanya sistem.

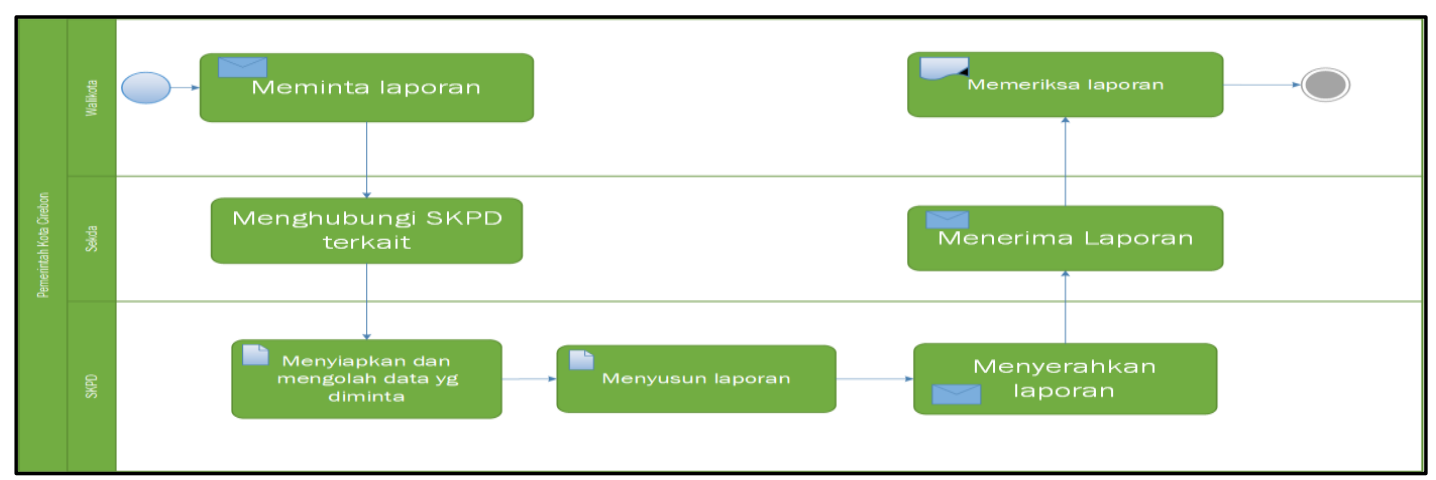


Gambar 2. Pemodelan proses bisnis as-is.

\section{f. Pemodelan Proses Bisnis To-Be}

Berdasarkan dari permasalahan yang terjadi pada proses bisnis sebelum adanya sistem informasi eksekutif, maka dapat didapatkan sebuah solusi yaitu dengan menyediakan sistem informasi eksekutif untuk pemerintahan Kota Cirebon. Pada Gambar 3 dan Gambar 4. menggambarkan pemodelan proses bisnis to-be yaitu suatu perbaikan proses bisnis setelah adanya sistem informasi eksekutif. Pada Gambar 3. menggambarkan pemodelan proses bisnis yang dilakukan oleh wali kota, wakil wali kota dan sekda dalam mendapatkan informasi yaitu pertama dengan melakukan akses kedalam sistem informasi eksekutif, kemudian memilih sektoral dan memilih data yang dibutuhkan. Lalu sistem akan meminta kedalam data warehouse dengan menjalankan sql untuk mendapatkan data. Setelah data didapatkan kemudian diproses oleh sistem untuk dilakukan visualisasi dalam bentuk grafik dan terakhir dapat ditampilkan untuk dilihat oleh pengguna sebelum top management yaitu walikota mengambil kebijakan.

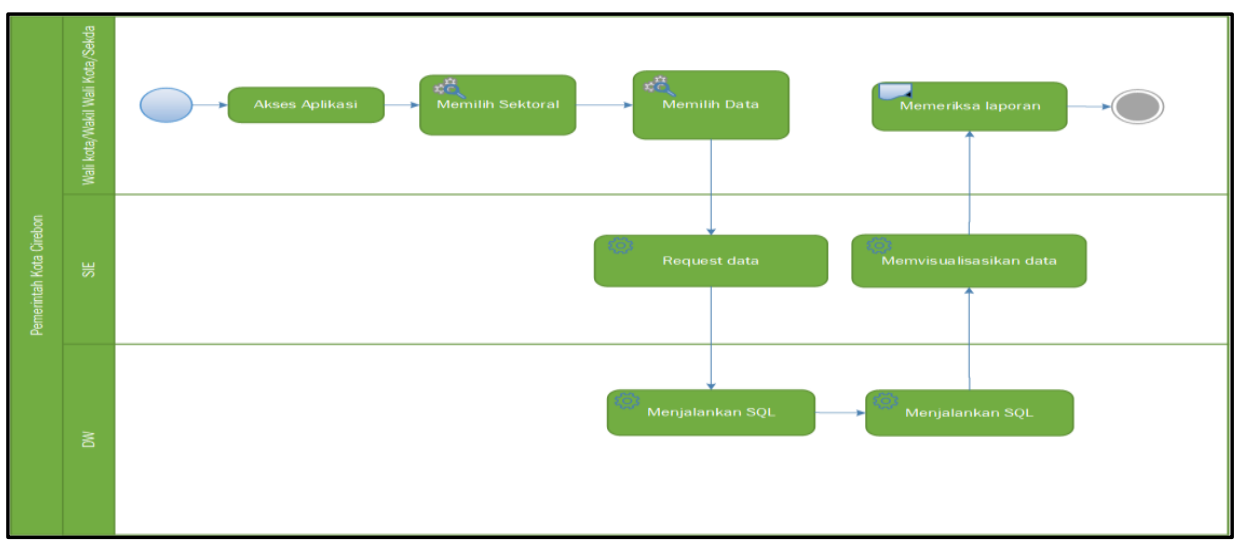

Gambar 3. Pemodelan proses bisnis to-be executive.

Kemudian pada Gambar 4. menggambarkan pemodelan proses bisnis yang dilakukan oleh kepala SKPD dalam mendapatkan informasi yaitu pertama dengan melakukan akses kedalam sistem informasi eksekutif, kemudian memilih data yang dibutuhkan. Lalu sistem akan meminta kedalam data warehouse dengan menjalankan sql untuk mendapatkan data. Setelah data didapatkan kemudian diproses oleh sistem untuk dilakukan visualisasi dalam bentuk grafik dan terakhir dapat ditampilkan untuk dilihat oleh pengguna, kemudian memproses tindaklanjut yang diminta oleh wali kota. 


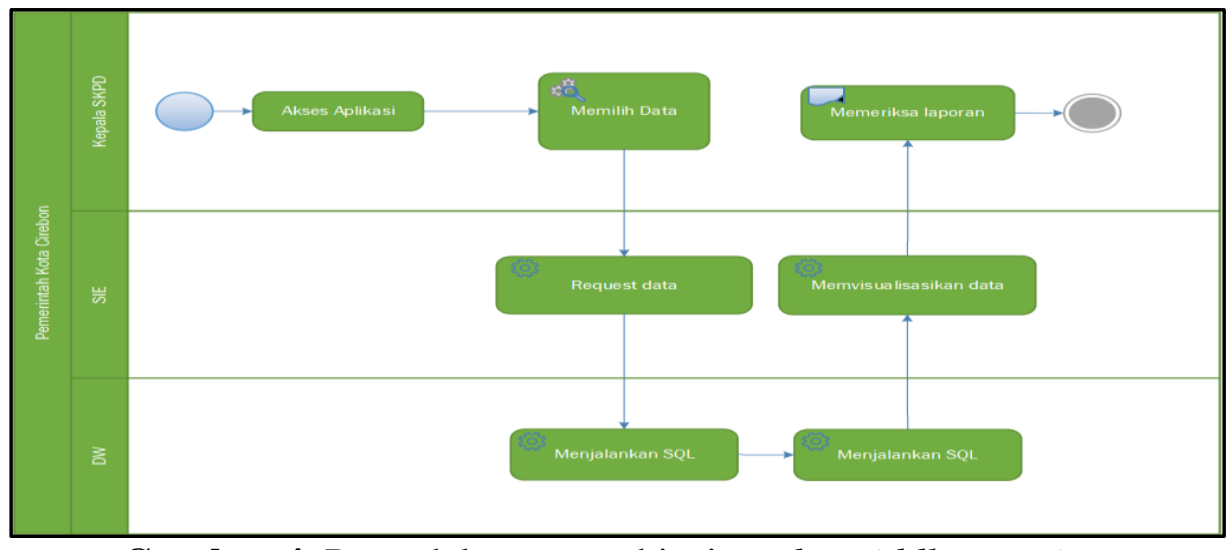

Gambar 4. Pemodelan proses bisnis to-be middle excutive.

\section{Hasil dan Pembahasan}

\subsection{Metode Pengembangan sistem}

Pada penelitian ini metode pengembangan sistem dengan menggunakan metode grapple. Metode grapple adalah salah satu metode pengembangan perangkat lunak yang berasal dari penyederhanaan metode pengembangan sistem Rappid Application Development. Menurut [11] metode grapple merupakan salah satu metodologi yang digunakan untuk pengembangan sistem yang pada setiap tahapan pengembangan sistem terdiri pada beberapa aktivitas yang harus dilakukan dan setiap aktivitas menghasilkan suatu design atau suatu produk berupa sebuah design diagram UML yang dikembangkan sebagai model visualisasi untuk membuat desain sistem dengan berorientasi objek [12].

\section{a. Requirement Gathering dan Analysis}

\section{User Story}

Identifikasi user story dilakukan untuk menentukan atau mengidentifikasi pengguna sistem dengan mendeskripsikan pengguna sistem dan memberikan gambaran pembagian antara pengguna satu dengan pengguna lainnya. Pada Tabel 1 menjelaskan mengenai identifikasi user story yang terbagi menjadi dua aktor yaitu eksekutif dan middle executive dengan melakukan pembagian lagi untuk pengguna yang termasuk diantara dua aktor tersebut. berikut hasil identifikasi user story:

Tabel 1. User Story

\begin{tabular}{|c|c|l|}
\hline $\begin{array}{c}\text { ID User } \\
\text { Story }\end{array}$ & Aktor & \multicolumn{1}{|c|}{ Deskripsi } \\
\hline US001 & Executive & $\begin{array}{l}\text { Pihak eksekutif pada actor ini merupakan eksekutif yang dapat mengakses } \\
\text { keseluruhan informasi pada sistem informasi eksekutif dalam membantu } \\
\text { pengambilan keputusan yaitu terdiri dari Walikota, Wakil Walikota dan Sekretaris } \\
\text { daerah. Infomasi yang diberikan pada actor ini merupakan keseluruhan sectoral } \\
\text { yang ada pada lingkungan pemerintahan Kota Cirebon }\end{array}$ \\
\hline US002 & $\begin{array}{c}\text { Middle } \\
\text { Executive }\end{array}$ & $\begin{array}{l}\text { Pihak eksekutif pada actor ini merupakan eksekutif yang ada dilingkungan } \\
\text { sectoral yaitu kepala SKPD. Hak akses yang diberikan pada kepala SKPD yaitu } \\
\text { hanya pada sectoral yang dibawah naungannya saja. }\end{array}$ \\
\hline
\end{tabular}




\section{Identifikasi Kebutuhan Pengguna}

Identifikasi kebutuhan pengguna dilakukan berdasarkan hasil dari wawancara dengan Kepala Bidang Statistik Sektoral dan Persandian. Hasil dari identifikasi kebutuhan pengguna terbagi menjadi dua yaitu kebutuhan fungsional dan kebutuhan non fungsional. Pada tabel 2, tabel 3 dan tabel 4 mendeskripsikan kebutuhan fungsional dan kebutuhan non fungsional dari sistem informasi eksekutif

Tabel 2. Identifikasi Kebutuhan Fungsional

\begin{tabular}{|c|l|}
\hline $\begin{array}{c}\text { ID Kebutuhan } \\
\text { Fungsional }\end{array}$ & \multicolumn{1}{|c|}{ Kebutuhan Fungsional } \\
\hline KF001 & Eksekutif dapat mengakses data dan informasi secara cepat dan kapan saja \\
\hline KF002 & $\begin{array}{l}\text { Penyajian informasi untuk eksekutif dalam bentuk grafik yang disesuaikan dengan bentuk } \\
\text { datanya }\end{array}$ \\
\hline KF003 & $\begin{array}{l}\text { Data dan informasi yang disediakan pada sistem terbagi menjadi 5 sektoral yaitu sektoral } \\
\text { ekonomi, kesehatan, pendidikan, kependudukan dan pemerintahan }\end{array}$ \\
\hline KF004 & $\begin{array}{l}\text { Walikota, Wakil Walikota dan Sekretaris Daerah dapat mengakses keseluruhan data yang } \\
\text { ada di seluruh sectoral di lingkungan Pemerintah Kota Cirebon }\end{array}$ \\
\hline KF005 & Kepala SKPD hanya dapat mengakses data di lingkungan SKPD \\
\hline KF006 & Hak akses sistem dapat terbagi berdasarkan penggunanya dan batasan akses pengguna \\
\hline
\end{tabular}

Tabel 3. Identifikasi Kebutuhan Non Fungsional

\begin{tabular}{|c|l|}
\hline ID Non Fungsional & \multicolumn{1}{|c|}{ Deskripsi } \\
\hline NF001 & $\begin{array}{l}\text { Sistem dibuat dengan berbasis web yang dapat diakses oleh browser pada smartphone } \\
\text { atau komputer. }\end{array}$ \\
\hline
\end{tabular}

b. Design

Arsitektur Sistem

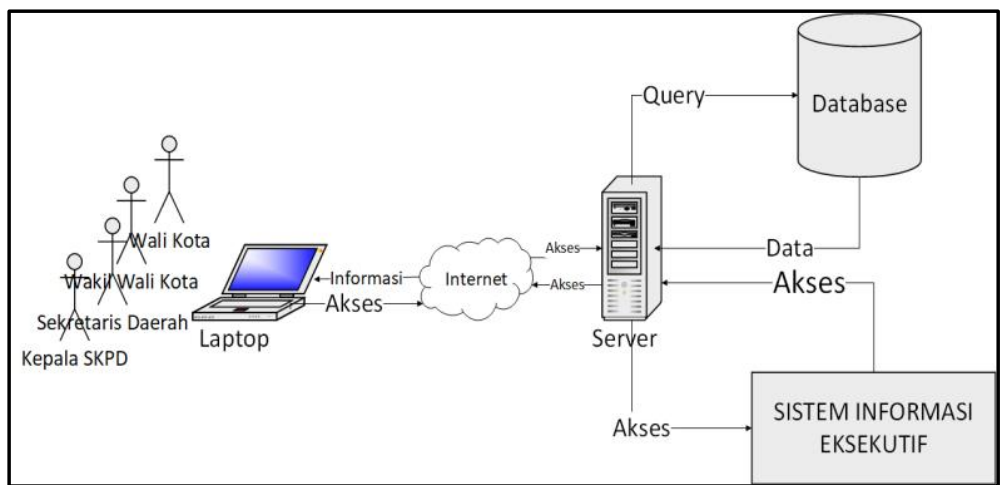

Gambar 5. Arsitektur Sistem Informasi Eksekutif.

Arsitektur pada sistem informasi eksekutif terbagi manjadi tiga bagian yaitu komponen pengguna, sistem dan data warehouse. Pada Gambar 5. menggambarkan arsitektur dari sistem informasi eksekutif yang dimulai dari pengguna yang dapat mengakses sistem informasi eksekutif melalui perangkatnya yang telah terkoneksi dengan internet. Kemudian internet tersebut akan terhubung dengan server sistem yang dapat menampilkan sistem informasi eksekutif dan juga mengakses database untuk mendapatkan data yang akan diolah oleh sistem informasi eksekutif. 


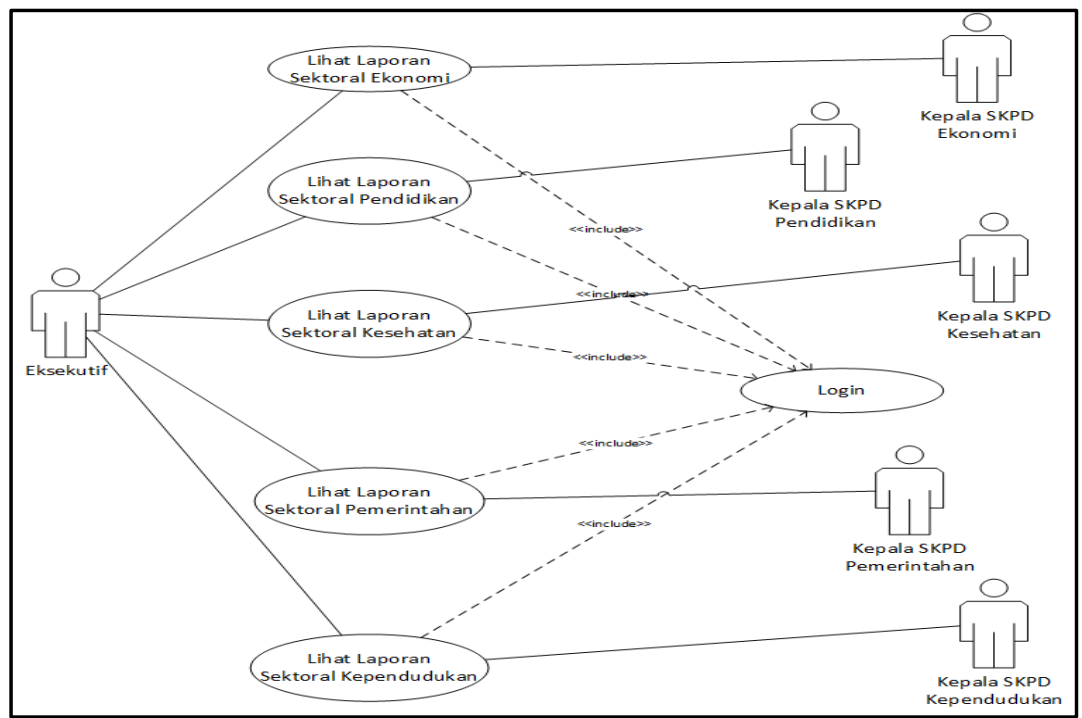

Gambar 6. Use Case Diagram

Use Case Diagram dapat menggambarkan interaksi atau suatu hubungan yang dilakukan antara actor dengan use case. Tujuan dari penggambaran dengan menggunakan use case diagram yaitu untuk menggambarkan tujuan dari actor dalam menggunakan sistem.

Activity Diagram

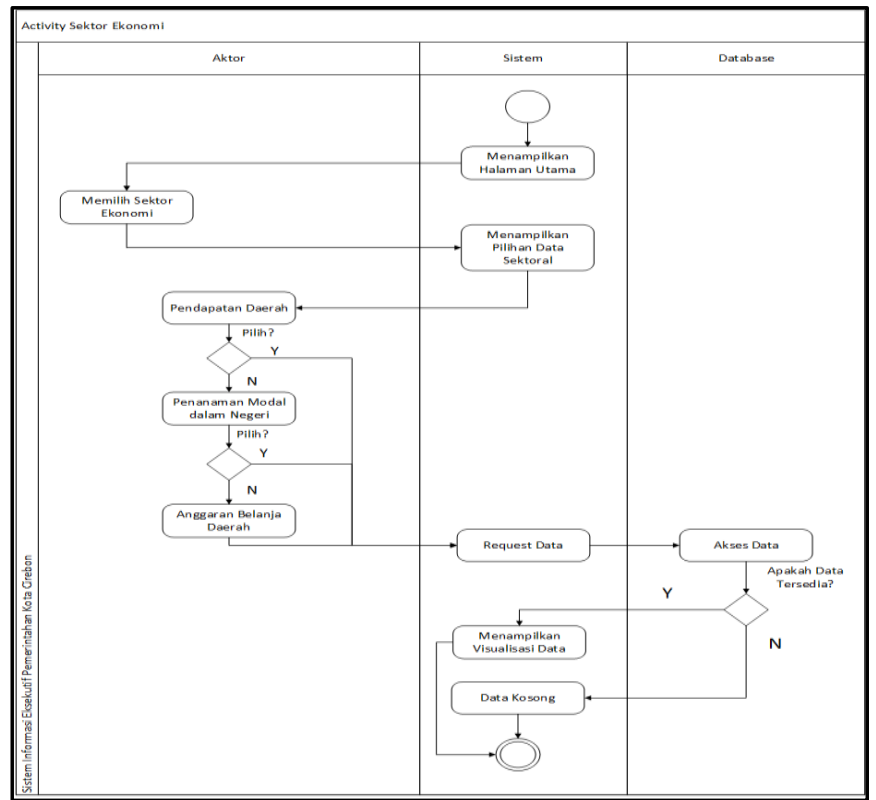

Gambar 7. Activity diagram lihat laporan sektoral ekonomi

Pada Gambar 7 menggambarkan sebuah activity diagram yang dapat diakses oleh eksekutif. Alur kerja dari activity diagram tersebut, eksekutif dapat mengakses sektor ekonomi secara 
keseluruhan dengan dapat memilih data berdasarkan kebutuhan dari eksekutif dalam mengakses informasi pada bagian tersebut. Pada akses yang diberikan oleh eksekutif tersebut tidak memiliki batasan akses untuk sektor tersebut dan dapat memilih keseluruhan informasi yang tersedia pada sektor tersebut.

\section{Sequence Diagram}

Pada Gambar 8 dibawah ini merupakan sequence diagram sektoral ekonomi yang digunakan sebagai penggambaran hubungan antara entity actor, entity boundary, object control dan object model.

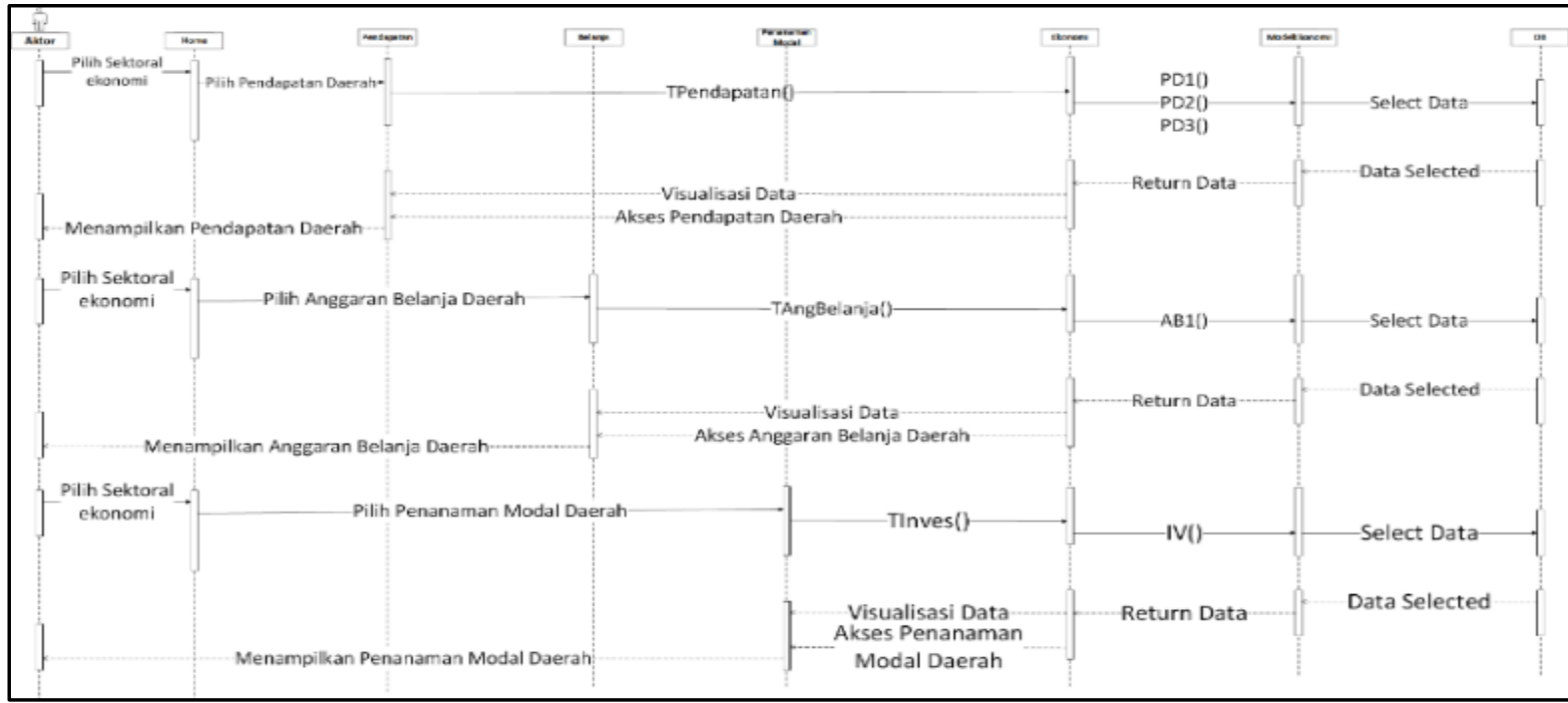

Gambar 8. Sequence Diagram Lihat Laporan Sektoral Ekonomi

\subsection{Implementasi Sistem}

Pada tahapan ini dilakukan implementasi sistem informasi eksekutif. Kode program disusun dengan menggunakan framework Code Igniter. Dan antarmuka dibuat dengan berbasis web yang sesuai dengan perancangan antarmuka yang telah dibuat sebelumnya.

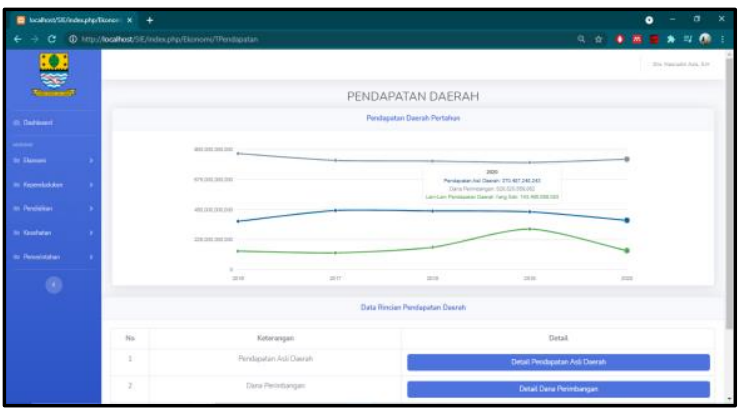

Gambar 9. Antarmuka Pendapatan Daerah

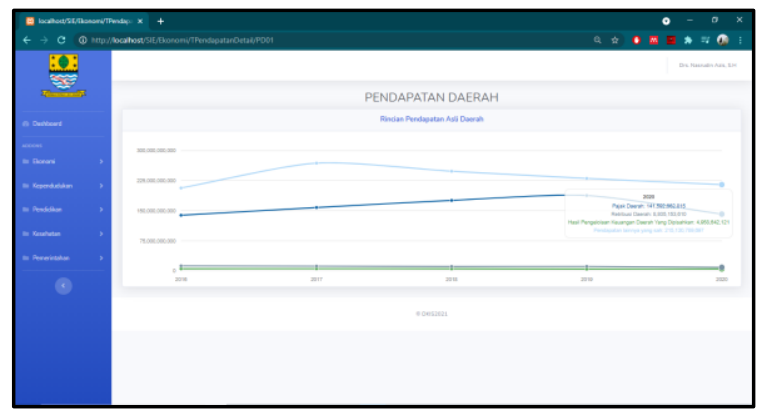

Gambar 10. Antarmuka Pendapatan Daerah

Pada Gambar 9 dan 10 merupakan antarmuka yang ditampilkan ketika pengguna memiliki hak akses untuk mengakses informasi pada sektor ekonomi. Pada halaman ini berisikan data pendapatan daerah dari sektor ekonomi. Pada Gambar 9 merupakan hasil visualisasi dari proses drill down dari Gambar 10 Untuk melakukan proses drill down terbagi berdasarkan sub data yang ada. 


\subsection{Pengujian Sistem}

Pada tahapan pengujian atau testing pada sistem informasi eksekutif dengan menggunakan metode pengujian yaitu black box. Tujuan menggunakan metode pengujian black box untuk menguji fungsional dari sistem apakah dapat berjalan dengan baik atau tidak [13]. Metode black box pengujian yang digunakan terdiri dari dua metode pengujian yaitu validation testing dan User Acceptance Testing.

\section{a. Validation Testing}

Pada tahap pengujian dengan menggunakan validation testing memiliki tujuan untuk memastikan fungsional dari sistem informasi eksekutif telah memenuhi kebutuhan fungsional yang diminta oleh pengguna [14]. Pada Tabel 4 menunjukkan hasil pengujian validation testing.

Tabel 4. Validation Testing

\begin{tabular}{|l|l|c|}
\hline No & \multicolumn{1}{|c|}{ Test Case } & Hasil \\
\hline 1 & Login Akun & Valid \\
\hline 2 & Lihat Laporan Sektoral Ekonomi & Valid \\
\hline 3 & Lihat Laporan Sektoral Kependudukan & Valid \\
\hline 1 & Lihat Laporan Sektoral Pendidikan & Valid \\
\hline 2 & Lihat Laporan Sektoral Kesehatan & Valid \\
\hline 3 & Lihat Laporan Sektoral Pemerintahan & Valid \\
\hline
\end{tabular}

Hasil pengujian validation testing yaitu berdasar Tabel 5 Hasil pengujian tersebut didapatkan berdasaran pengujian yang telah dilakukan sesuai dengan test case yang telah dibuat. Maka hasil dari pengujian validation testing yaitu $100 \%$ sesuai dengan kebutuhan fungsional.

\section{b. User Acceptance Testing}

User Acceptance Testing (UAT) merupakan salah satu metode pengujian sistem yang dilakukan oleh pengguna dan menghasilkan sebuah dokumentasi pengujian yang dijadikan sebagai hasil dengan menandakan bahwa pengguna dapat menerima pengembangan suatu perangkat lunak [15]. Hasil dari proses pengujian dengan UAT didapatkan berdasarkan hasil dari pengguna mengerjakan test case yang telah disediakan. Berikut hasil dari pengujian UAT berdasarkan test case:

Tabel 5. User Acceptance Testing

\begin{tabular}{|l|l|c|}
\hline No & \multicolumn{1}{|c|}{ Test Case } & Hasil \\
\hline 1 & Hak Akses Sistem & $85 \%$ \\
\hline 2 & Lihat Laporan Sektoral Ekonomi & $82.86 \%$ \\
\hline 3 & $\begin{array}{l}\text { Lihat Laporan Sektoral } \\
\text { Kependudukan }\end{array}$ & $92 \%$ \\
\hline 4 & Lihat Laporan Sektoral Pendidikan & $88.57 \%$, \\
\hline 5 & Lihat Laporan Sektoral Kesehatan & $80 \%$ \\
\hline 6 & Lihat Laporan Sektoral Pemerintahan & $82.86 \%$ \\
\hline \multicolumn{2}{|r|}{ Rata-Rata } & $85.29 \%$ \\
\hline
\end{tabular}

Pada pengujian UAT mendapatkan hasil yang didapatkan pada pengujian ini untuk rata-rata keseluruhan $85.29 \%$. Nilai tersebut memiliki arti yaitu sistem informasi yang dikembangkan dapat diterima oleh organisasi maupun eksekutif sebagai pengguna sistem. 


\section{Kesimpulan dan Saran}

Berdasarkan penelitian yang telah dilakukan yaitu Pengembangan Sistem Informasi Eksekutif Pemerintahan Kota Cirebon, Pengembangan sistem informasi eksekutif di pemerintahan kota Cirebon telah membantu eksekutif yaitu terdiri dari wali kota, wakil walikota dan sekretaris daerah dan middle executive yang terdiri dari kepada skpd di lingkungan pemerintahan kota Cirebon. Sistem informasi eksekutif pemerintahan kota Cirebon teridiri dari lima sektor yang ada di kota Cirebon yaitu ekonomi, kesehatan, kependudukan, pendidikan dan pemerintahan. Implementasi yang dilakukan pada sistem informasi eksekutif dengan berbasis web yang merangkum keseluruhan informasi dari kelima sektor tersebut.

Pengujian sistem informasi eksekutif dengan menggunakan metode pengujian black box yaitu validation testing dan user acceptance testing. Pada validation testing mendapatkan $100 \%$ valid yang berarti test case dengan proses pengujian telah sesuai dengan kebutuhan fungsionalnya. Kemudian pada user acceptance testing mendapatkan hasil rata-rata untuk keseluruhan sebesar $85.29 \%$.

Pada penelitian ini masih terdapat kekurangan, penulis ingin menyampaikan beberapa saran yang dapat digunakan sebagai pertimbangan pada penelitian Pengembangan Sistem Informasi Eksekutif Pemerintahan Kota Cirebon. Selanjutnya pengembangan sistem informasi eksekutif tahap berikutnya dapat melibatkan keseluruhan sektor pemerintahan yang ada di pemerintahan kota Cirebon. Perlu adanya evaluasi dan perbaikan antarmuka dari sistem informasi eksekutif pemerintahan kota Cirebon yang dapat digunakan sebagai acuan dalam pengembangan tahap berikutnya.

\section{Daftar Pustaka}

[1] M. H. Prayitno, "Sistem Informasi Eksekutif Pemasaran Dengan Metode Drill Down," vol. 17, no. 3, hal. 105-110, 2017.

[2] H. A. Nugroho, M. I. Afandi, dan R. Hadiwiyanti, "Sistem Informasi Eksekutif Berbasis Web Dengan Framework Codeigniter (Studi Kasus: PT Samudera Sarana Logistik), J. Inform. dan Sist. Inf., vol. 1, no. 1, hal. 248-254, 2020.

[3] R. Muhammad, W. Witanti, dan Melina, "Pembangunan Sistem Informasi Eksekutif Pada Dinas Pendidikan Kabupaten Purwakarta," SEMNATI, vol. 2, hal. 311-316, 2019.

[4] A. Khadir, Pengantar Sistem Informasi. 2014.

[5] F. Fatoni, "Kerangka Kerja Sistem Informasi Eksekutif Perguruan Tinggi," J. Teknol. Inf. dan Ilmu Komput., vol. 6, no. 3, hal. 257, 2019, doi: 10.25126/jtiik.201963946.

[6] E. Y. Anggraeni, "Pengantar Sistem Informasi," in Penerbit Andi, 2017.

[7] J. Hutahaean, Konsep sistem informasi. 2015.

[8] R. A. F. Ismubandono, W. Hayuhardhika, N. Putra, dan D. Pramono, "Analisis dan Perancangan Sistem Informasi Eksekutif Dashboard Data E- Government berbasis Service pada Pemerintah Kabupaten Sidoarjo," J. Pengemb. Teknol. Inf. dan Ilmu Komput., vol. 3, no. 11, hal. 10788-10796, 2019.

[9] S. Hidayat, S. E. Anjarwani, dan I. W. A. Arimbawa, "Rancang Bangun Sistem Informasi Eksekutif Pada STAHN Gde Pudja Mataram,” J. Comput. Sci. Informatics Eng., vol. 2, no. 2, hal. 100-105, 2018, doi: 10.29303/jcosine.v2i2.39.

[10] Widiyanto, “Analisis Proses Bisnis Usaha Mikro Kecil Menengah (Umkm) Konveksi Ryan Collection Di Kabupatan Kudus," J. Adm. Bisnis, vol. 6, no. 1, hal. 24-30, 2017, 
doi: 10.14710/jab.v6i1.16603.

[11] J. Schmuller, No TNo Sams Teach Yourself UML in 24 HoursTitle.itle. 2004.

[12] M. Maimunah, I. Ilamsyah, dan M. Ilham, "Rancang Bangun Aplikasi Penjualan Furniture Online Pada Mitra Karya Furniture," CSRID (Computer Sci. Res. Its Dev. Journal), vol. 8, no. 1, hal. 25, 2016, doi: 10.22303/csrid.8.1.2016.25-36.

[13] M. Y. P. Mahendra, I. N. Piarsa, dan D. Putra Githa, "Geographic Information System of Public Complaint Testing Based On Mobile Web (Public Complaint)," Lontar Komput. J. Ilm. Teknol. Inf., vol. 9, no. 2, hal. 95, 2018, doi: 10.24843/lkjiti.2018.v09.i02.p04.

[14] Y. Kurniawan, W. Hayuhardhika, N. Putra, dan W. Purnomo, "Pengembangan Sistem Informasi Eksekutif Dashboard E-Government Berbasis Website Menggunakan Metode Rational Unified Process ( Studi Kasus : Dinas Komunikasi dan Informatika Kabupaten Sidoarjo )," vol. 3, no. 7, hal. 7180-7187, 2019.

[15] N. Aini, S. A. Wicaksono, dan I. Arwani, "Pembangunan Sistem Informasi Perpustakaan Berbasis Web menggunakan Metode Rapid Application Development (RAD) (Studi pada : SMK Negeri 11 Malang)," J. Pengemb. Teknol. Inf. dan Ilmu Komput., vol. 3, no. 9, hal. 9, 2019. 